\title{
The use of historical data for the characterisation of multiple damaging hydrogeological events
}

\author{
O. Petrucci ${ }^{1}$ and M. Polemio ${ }^{2}$ \\ ${ }^{1}$ CNR-IRPI Rende (CS), Italy \\ ${ }^{2}$ CNR-CERIST Bari, Italy
}

Received: 27 November 2001 - Revised: 17 June 2002 - Accepted: 28 June 2002

\begin{abstract}
Landslides, floods and secondary floods (hereinafter called phenomena) triggered by rainfall and causing extensive damage are reviewed in this paper. Damaging Hydrogeological Events (DHEs) are defined as the occurrence of one or more simultaneous aforementioned phenomena.

A method for the characterisation of DHEs based upon historic data is proposed. The method is aimed at assessing DHE-related hazard in terms of recurrence, severity, damage, and extent of the affected area. Using GIS, the DHEs historical and climatic data collection, the geomorphological and hydrogeological characterisation of the hit areas, the characterisation of induced damage, the evaluation of triggering rainfall return period and critical duration of each DHE were carried out.

The approach was applied to a test site in Southern Italy (Calabria) for validation purposes. A database was set up including data from 24 events which have occurred during an 80 -year period. The spatial distribution of phenomena was analysed together with the return period of cumulative rainfall. The trend of the occurred phenomena was also compared with the climatic trend. Four main types of Damaging Hydrogeological Events were identified in the study area.
\end{abstract}

\section{Introduction}

Landslides, floods and secondary floods (i.e. rapid accumulation or pounding of surface water with very low flow velocity), hereinafter called phenomena, can be a source of recurrent economic damage resulting from heavy rainfall. The Damaging Hydrogeological Events (DHEs) can be defined as the occurrence of one or more simultaneous aforementioned phenomena causing damages.

Long phenomena-free periods can be abruptly interrupted by short catastrophic events, during which many concurrent phenomena are triggered. Due to the simultaneous triggering of various types of phenomena, DHEs can be treated as

Correspondence to: O. Petrucci (petrucci@irpi.cs.cnr.it) a source of multiple hazard (AA.VV., 1983). Geomorphologists are seeking to bridge knowledge gaps in the physical features of individual hazardous events, but the wealth of information provided by social scientists and gained throughout planning activities needs to be presented in an appropriate format for it to be put to use and tapped (Gare et al., 1994). A comprehensive approach is required to manage the full range of phenomena which are triggered by rainfall during DHEs. The characterisation of phenomena and the underlying triggering rainfall can serve as a basic building-block to outline the DHE features.

The described research activity is based on historical data rather than on the systematic, multi-temporal geomorphological air photo interpretation. The selected approach, though imposing some limitations on the utilisation of results, allows one to study old events (for which air photos are not available), to associate triggering daily rainfall to each event and to assess damage.

\section{Phenomena caused by DHEs}

In this paper, the damaging phenomena which have been triggered by heavy or relentless rainfall are subdivided into three main groups: landslides (all natural types included; all artificial slopes, cuts or embankments, excluded) river floods (including flash floods), and secondary floods, as previously defined.

Among the reviewed types of phenomena, river floods are those for which forecasting and warning are easier to implement (Yevjevich, 1992). Precipitation leading to major floods usually takes one or more days to cause sufficient runoff build-up and to initiate the whole process. By contrast, in the case of sudden flash floods, occurring in small basins, advance alert is no easy task, because rainfall-runoff conversion is so rapid that it does not allow one to forewarn people living alongside the river. Fortunately, unlike landslide phenomena, river floods can only affect specific areas: the sectors adjacent to the river network. Flooding prone areas can be traced 
using geomorphological criteria (Maraga, 1990) and classified according to the return period of the floods which have hit them (Natale and Versace, 1995).

Real-time flood forecasting has been thoroughly investigated over the past few years. The mathematical, statistical, meteorological or hydrological models which have been proposed in the scientific literature and which rely on data sets collected by real-time hydrological monitoring systems ensure reliable flow forecasts, particularly for heavy floods (Ubertini, 1990; Schultz, 2000; Samuels, 2000; Krzysztofowicz, 2001).

In river basins for which historical flow records are not available, a geomorphological approach can be used. Based on both the river morphology and the stream pattern during the past floods, the river course is subdivided into segments and characterised according to their varying response to the extreme events (Baker et al., 1988; Rosgen, 1994; Govi and Turitto, 1994a; Iovine and Petrucci, 1998).

As far as landslides are concerned, the international literature widely recognizes that rainfall is the most common triggering cause (Crozier, 1986; Corominas, 2001), but the relationship between rain and slope instability is not as direct as in the case of floods. The rain that triggers landslides varies widely from one area to the next, and it can change as a function of the mean annual precipitation; the magnitude of the event depends on rainfall intensity and on the season of occurrence (Campbell, 1975; Caine, 1980; Crozier, 1986; Keefer et al., 1987; Wieczoreck, 1987; Sandersen et al., 1996; Au, 1998). Hence, the same amount of rain which falls on different areas may, despite the similarities in geolithological and morphological features (Govi et al., 1985), produce a wide range of instability conditions.

An overview of recent international research identifies eight main methods to analyse rainfall-triggered landslides (De Vita and Reichenbach, 1998; Polemio and Petrucci, 2000): (1) rainfall duration-intensity threshold methods, (2) cumulative and antecedent rainfall methods, (3) long cumulative rainfall methods, (4) actual rainfall methods, (5) simplified hydrogeological or soil water balance methods, (6) combined rainfall and stability analysis methods, (7) complete slope methods and (8) spatial models, mostly GISbased. Except for the last method, the approach is gradually less empirically, qualitatively- and statistically-oriented and more physically-, hydrologically- and geotechnically-based. GIS-based models are the newest; they use georeferenced data pertaining to many variables, such as rainfall, terrain slope and exposure, altitude, distance from drainage network, and thickness of superficial terrains.

Secondary floods are very common phenomena which occur during DHEs even when they are not caused by rainfall of a high return period. Damage to people and urban or rural settlements can range from low to medium, according to the type of land use in the concerned area. Secondary floods include what is known in the literature as urban flooding (Marco and Cayuela, 1992) which occurs when rain falls on impervious locations, such as streets, roofs, and paved areas and produces very fast flowing runoff. Within a short time, water, if not collected into the storm-water system, can be conveyed into the ground surface depressions and flood them. Pounding water can also cause extensive damage to farming, especially on quasi-impervious soils. Similarly, secondary floods can be due to specific morphological configurations, such as endorheic areas, low gradient areas or areas lacking a suitable natural or artificial drainage network (Polemio, 1998).

\section{Methodology}

The classification of DHEs is based on the comparative analysis of triggering rainfall and resulting phenomena (landslides, floods and secondary floods). The analysis takes into account the main climatic, geological, geomorphological features and human agency within the study area. The study area must be vast enough to yield sufficient data on both rainfall and damage, and to exhibit a geomorphologically and hydrologically homogenous configuration.

\subsection{Characterisation of the study site}

The preliminary characterisation of the study area requires: (a) the collection of available geological data; (b) the collection of available geomorphological data; (c) the validation of data collected in steps (a) and (b) through air photo interpretation and on-site surveys of the areas damaged by DHEs; and d) the collection of data on urbanised areas and the evolution thereof.

Starting from published geological maps, a lithological map can be drawn grouping geological formations into some main lithological types.

As for point (d), research should focus on the evolution of land use, settlements and communication networks servicing the area. For instance, in Calabria (Southern Italy), between the end of the 19th Century and the beginning of the 20th Century, villages developed inland from the west coast on inaccessible - and unstable - slopes, to guard against the enemy (coming from the sea) and malarial fever (sweeping across the swampy coastal plains) (Antronico et al., 1998). The most commonly occurring phenomenon in these villages was landslide, whereas those villages which developed after the 1950s suffered a different fate. Following land reclamation along the coastal plains, many rural settlements grow rapidly on flat - and stable - areas along the rivers, within reach of water resources. These settlements are landslidefree, but they lie largely diffused on flood-prone areas.

This wealth of information must be mapped in order to proceed with data processing, to set up a Geographic Information System and identify those areas which are particularly liable to DHEs.

3.2 Collection, preliminary analysis and georeferencing of historical data

A long series of historical and technical sources must be analysed in order to set up a database concerning all the phenom- 
ena which have been recorded over a long period of time. The research aims to:

1. broaden the study period;

2. fill the gaps in the series;

3. gather more technical details about the events.

Many authors (Ibsen and Brunsden, 1996; Govi and Turitto, 1994b; Guidoboni, 1995; Flageollet et al., 1999; Guzzetti, 2000) have highlighted the problems which are commonly associated with the use of historical data. Historical information is often derived from non-scientific sources and cross checked prior to its validation via a comparison with the hydrological/statistical characteristics of each known DHE.

A host of sources can be analysed, namely: (a) available databases, e.g. the AVI Project, for Italy (CNR-GNDCI, 1995) and the ASICal database, for Calabria (Petrucci and Versace, 2000), spanning from the year 1100 to the year 2000; (b) historical sources; (c) popular books and reviews; (d) documentation available in national and local archives (e.g. the correspondence between local and regional or national authorities concerning the financial support to cope with landslides or flood phenomena); (e) newspapers and (f) scientific publications. No less important are epigraphs, parish registers and archives, technical notes taken by or for Civil Protection staff or personal communications by persons living in the areas where these phenomena have occurred. The above described steps help set up the historical series of DHEs occurring in a given study area. Despite some gaps pertaining to phenomena which have occurred in scarcely populated areas or during specific historical periods (e.g. wars), these series account for the most severe DHEs, and can be compared with the findings of both hydrologic and geomorphologic analyses. The analysis of the historical database allows one to identify a day or a short time frame, which is characterised by the occurrence of one or more damaging phenomena. When the cross check with rainfall data sets shows that one of these events corresponds to an absolutely ordinary rainfall period or to a dry period, data on these phenomena are ruled out by the subsequent hydrolog$\mathrm{ical} /$ statistical analyses. This is often the case when sources are unreliable. In some other instances the events cannot be directly linked to the rainfall, as is the case for landslides which earthquakes or human actions have triggered. Historical data are organised in a single short time frame (generally never exceeding 10 days), each accounting for a catalogued damaging hydrogeological event. Then, the recorded events are grouped according to their month of occurrence and the seasonal distribution of the DHEs is evaluated. Hence, it is possible to determine the DHE regime - the total monthly DHEs - to compare it to the climatic trend and some other seasonal variables, and proceed with a case-by-case evaluation (e.g. the regimen of springs or human-related parameters).

Based on the accuracy and availability of reports, data can be subdivided into two groups:
1. data concerning phenomena which have occurred at specific sites;

2. data concerning phenomena of widespread occurrence or described by toponyms associated to wide areas.

In the latter, the problem arises of georeferencing a vast area the boundary is not well defined. In order to bypass this problem, the area can be subdivided into irregular cells and phenomena can be counted in the cells. Intersecting the boundaries of the watersheds with the administrative boundaries draws the cells, because data are generally described with reference to the rivers and towns. For each hydrogeological event, the various types of triggered phenomena (landslides, floods and secondary floods) can be plotted on a cell-map.

In order to analyse the distribution of the phenomena in each cell area $A_{c}$, the density of events can be plotted using a normalisation criterion. A density factor $\left(D_{c}\right)$ has been calculated, for each cell $c$, in which $N_{c}$ phenomena occurred, as total of all DHEs:

$D_{c}\left(\frac{1}{10^{-4} \mathrm{~km}^{2}}\right)=\frac{N_{c}}{A_{c}\left(\mathrm{~km}^{2}\right) \sum N_{c}} 10000$.

The mean recurrence period of the phenomena which have occurred in each cell can be statistically analysed.

In order to analyse the time recurrence of one or more types of phenomena, a time factor $\left(T_{c}\right)$ can be calculated, for each cell $c$, expressed as follows:

$T_{c}($ years $)=\frac{\Delta T}{N_{c}}$,

where $\Delta T$ is the study period (years).

The land use and the human features of each cell affect the availability of historical data. All types of phenomena, both landslides and floods, can cause historically known damage only if there were either property or people affected. When scarcely populated small cells are phenomena-free, the analysis of data referring to the nearby cells can help verify whether the finding is ascribable to a gap in the data set or whether the cells are actually phenomena-free.

\subsection{Analysis of the hydrological and climatic data sets}

The definition of the climatic settings in the study area is based mainly on the available historical series of daily, monthly and annual rainfall.

Monthly temperature and rainfall are necessary to assess the hydrologic balance for the mean year. The ThornthwaiteMather method (1957) helps determine the mean monthly amount of actual evapotranspiration and rainfall, and the duration of dry and wet seasons. Then the resulting actual rainfall regime can be compared to the regime of the phenomena.

Daily rainfall data are necessary to determine the rainfall return period of each DHE. Monthly and annual rainfall data help characterise the climatic trend of the period for which data are available. The characterisation of the impact of climatic changes is useful as these changes are likely to affect the regime, the frequency and/or the intensity of DHEs. 
Therefore, the analysis of the climatic trend is used to evaluate the steady character of the data set rather than to characterise each DHE.

In order to assess the impact of the climatic trend, especially changes in the rainfall rate, an annual rain index $\left(I r_{y}\right)$ can be calculated for each single year $(y)$ and applied to the whole area:

$\operatorname{Ir}_{y}(\%)=\frac{\sum_{i} A P_{i, y}}{\sum_{i} M A P_{i}} \%$.

$A P_{i, y}$ is the Annual Precipitation at gauge $i ; M A P_{i}$ is the Mean Annual Precipitation at gauge $i ; i$ is the number of available gauges in the year $y$. Ir $r_{y}$ should be defined considering the hydrological year rather than the solar year and compared to the number of phenomena for each hydrologic year.

In order to establish the most significant rain gauges for each cell, a range of hydrological methods can be used (ASCE, 1996). At the end of this step, every cell should be linked to the most significant rain gauge.

If a lack of rainfall data is detected for a specific cell-DHE, the availability of other significant gauges should be verified. If the outcome is negative, the DHE will not be discussed from the hydrological and statistical point of view for that cell.

The response of the study area to periods of high-intensity and/or long-lasting precipitation can be inferred by applying empirical statistical models which quantify the rainy period associated with the catastrophic event in terms of return period. It is suggested to utilise a statistical method that quantifies the cyclicity or the exceptional character of rainfall which can be associated with the catastrophic event (Cascini and Versace, 1986; Polemio and Sdao, 1999). At each rain gauge, the daily Cumulative Rainfall variables $C R_{n j}$ are taken into account, where $n$ corresponds to $1,5,10,20,30$, $60,90,120$ and 180 consecutive days, and $j$ is the number of measurement days during the study period.

The effects of antecedent rainfall generally decay more quickly for floods than for deep landslides. Polemio and Sdao (1999) showed the important role of both recent and antecedent rainfall on deep landslide reactivation in the Avigliano area (Southern Italy). In this case the significant effect of no recent rainfall was reasonably linked to the groundwater recharge of the landslide body. Moreover, decay factors were successfully used when a single type of phenomenon involved homogenous lithological areas, as is the case for the landslides described by Capecchi and Focardi (1988). The use of decay factors is extremely complex wherever various lithologies are involved, as was shown in a study on landslides of a wide region in which Avigliano is located (Naden et al., 1993). $C R_{n j}$ should be determined without using a presumptive decay factor. Assuming the same weight for recent or antecedent daily rainfall should be necessary in a preliminary characterisation of DHEs.

The peak or extreme values $C R M A X_{n, y}$ are inferred per each single year $y$, per each $\mathrm{n}$ and per each gauge from the daily data series. The annual peak values assumed by $C R_{n j}$ are analysed.

The study of the annual peak of cumulative rainfall can be based on the so-called GEV (Generalised Extreme Value) probability distribution function which is defined by three parameters: scale, location and shape (Jenkinson, 1955). The GEV parameters can be defined by the method of the Probability-Weighed Moments, known as PWM (Hosking et al., 1985). By changing $n$ and the station, the parameters of the GEV function are defined for each series of cumulative rainfall.

A wide time window is required to analyse $C R_{n j}$ for each DHE. A time window of 150 days is proposed, covering 90 days before the occurrence of the DHE and 60 days after it. Such a long time window is needed to evaluate the effect of date errors, common with old historical information (for instance, the reported date can often be confused with the event date). Sometimes a delay in the spreading of information can occur. In the case of slow landslides, as an example, the beginning of activation cannot be well defined, but the date of the most dangerous macroscopic displacement can be more exactly established.

For each DHE, the return period of every $C R_{n j}$ is assessed within this time window for all the rain gauges referring to cells affected by the phenomena. The most significant day for each gauge/hydrogeological event, in terms of the $C R_{n j}$ return period, is preliminary set equal to the DHE starting day. The effect of short, previous and long-lasting rainfall is evaluated by comparing the return period distribution of the daily cumulative rainfall $C R_{n j}$, considering mainly the maximum return period. A case-by-case analysis is necessary to identify the most significant day, particularly if the DHE frame is longer than one day. In this case the day of the highest return periods should be generally selected. If the maximum return period of the most significant day of any $C R_{n j}$ is extremely low, that event should not be considered as a damaging event caused by rain. This minimum threshold should be evaluated on a case-by-case basis, assuming a cautious low value and eventually increasing it after a preliminary DHEs characterisation. It is suggested to assume a cautious value of two years for the minimum return period threshold: cumulative rainfall below this threshold is extremely common rainfall which actually takes place almost every year. The minimum return period threshold should be extremely low with respect to the mean recurrence period of a specific DHE type. In any case, extremely low return period values are unexpected for floods phenomena, but they can be more common for landslides since many other causes can trigger them.

The critical duration for each gauge/DHE can now be determined considering the durations of $C R_{n j}$ with higher return periods. The analysis is mainly based on daily rainfall due to the lack of stream flow gauging stations (water surface elevation gauge) which characterises the hydrographic networks in many areas worldwide and particularly in Southern Italy and in the study area. In this region, the torrential 
regime of rivers does not permit a systematic collection of river flow data.

\subsection{Characterisation of DHEs}

DHE types can be distinguished based on the following features:

1. types of phenomena which are more widely triggered,

2. sectors which are more intensely and/or frequently hit,

3. season of occurrence,

4. mean recurrence period,

5. return periods of the triggering precipitation of various duration,

6. critical duration of the triggering rainfall,

7. magnitude of damage.

The first four points characterise the phenomena, points 5 to 6 describe rainfall features and the last point takes into account the impact of DHEs on human settlements. A damage classification can be performed establishing a priori three damage levels as follows (Petrucci and Versace, 2000):

Level 1: high damage

At least one of the following circumstances occurs:

- breaking of bridges

- damage to main roads and railway lines

- serious blocking of roads and railways lines to the extent that transitability is rendered impossible

- damage to major life-lines

- collapse of buildings

- flooding of vast areas of land with great damage to agriculture

- occurrence of victims and casualties.

Level 2: medium damage

The circumstances of Level 1 do not occur but at least one of the following does:

- some building rendered unusable

- landslides and/or flooding that affect road and railways, though with limited effects and brief duration

- damage to secondary life-lines

- flooding of limited areas of land with serious damage to agriculture.

Level 3: low damage

The circumstances of Levels 1 and 2 do not occur and just one of the following happens:

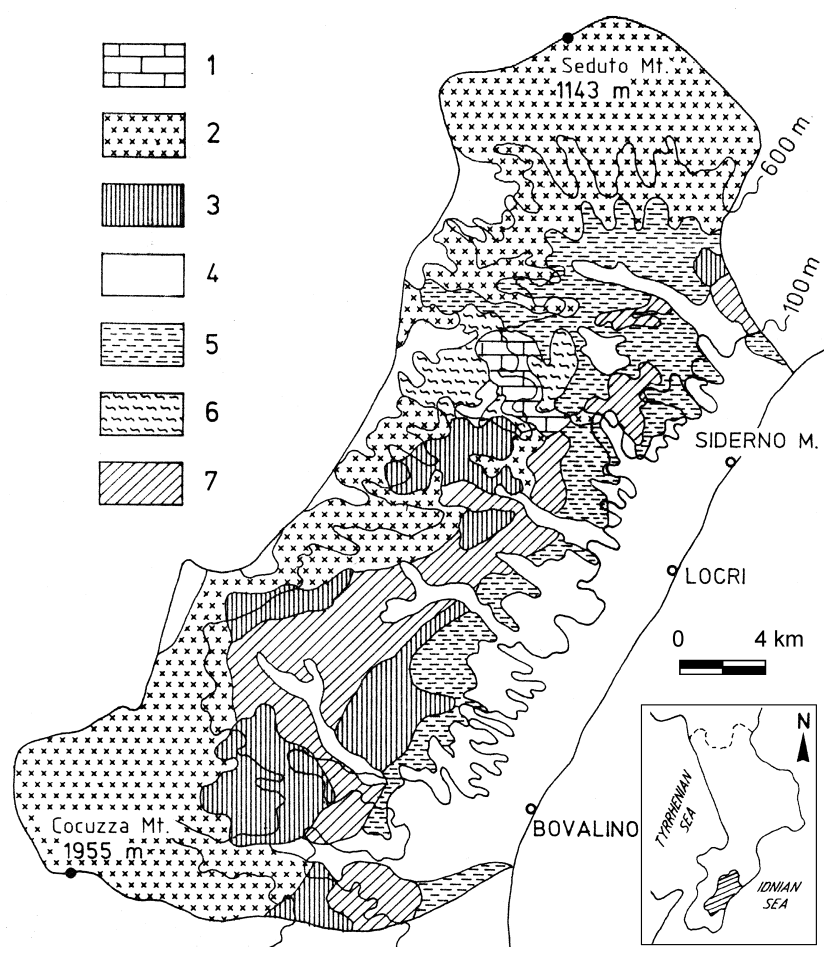

Fig. 1. Geological map (Petrucci and Polemio, 2002). (1) Limestone and dolostone, (2) metamorphic and acid igneous rocks, (3) cohesive sedimentary lithotypes, (4) noncohesive sedimentary lithotypes, (5) pelites with evaporitic layers, (6) low-grade metamorphic rocks, (7) flysch.

- damage to agriculture OR

- flooding of inhabited areas OR

- damage to life-lines.

\section{Study area}

The described methodology has been tested in a selected area located in Southeast Calabria (Italy). Hydrogeological events have severely affected the Calabria region. From 1946 to 1990, DHEs have claimed 180 lives, 165 of which in the district of Reggio Calabria (Catenacci, 1992). Between 1950 and 1973 , along $988 \mathrm{~km}$ of railway, 44 interruptions due to landslides and floods have been reported (Lanzafame and Mercuri, 1975); and from 1971 to 1980 , river floods have destroyed 31 bridges in the whole region (Petrucci et al., 1996).

The average annual rainfall in the region is $1151 \mathrm{~mm} / \mathrm{y}$.

\subsection{Geological setting}

The study area is located in the district of Reggio Calabria, along the southern Ionian border of Calabria region. The area is also called Locride, after the name of the old Grecian colony that exerted a deep influence on the area. It covers about $686 \mathrm{~km}^{2}$, at an elevation ranging between sea level and $1900 \mathrm{~m}$ a.s.l. 
The area is a sector of the "Arco Calabro-Peloritano", a fragment of the Southern Apennines, a NE verging thrust belt which originated in the Miocene-Pleistocene age (AmodioMorelli et al., 1976).

The area encompasses a sequence of NE-SW-oriented packs of varying lithology, as shown by the simplified lithological map (Petrucci and Polemio, 2002). Metamorphic and locally poorly tectonised intrusive acid rocks outcrop in the mountain sectors. On the hills, detritic sedimentary rocks are prevalent, mostly sandstone but also Jurassic limestone. In the transition zones towards the lowland, flysch and pelitic sedimentary rocks, inter-bedded with evaporitic deposits, outcrop. Close to the coast, loose, terraced sediments prevail, consisting of continental and marine Plio-Quaternary deposits (Fig. 1).

Geomorphologically, the area is a platform which has a round-shaped summit and is eastward bound by steep flanks and a narrow coastal plain. The plain is crossed by "fiumare", local torrential watercourses. The relief is characterised by neotectonic uplifting with a marked differential (Ibbeken and Schleyer, 1991). The whole area is affected by erosion processes and slope movements of various sizes, from superficial soil slips to deep-seated gravitational slope deformations (Guerricchio and Melidoro, 1973). The earthquake that had the most serious effect (Macroseismic Equivalent Magnitude equal to 6.8, at Gerace village) on the area took place in 1783 (Boschi et al., 1997).

\subsection{Human settlements}

The Locride area is scarcely populated and the population decreases inland. In the existing 22 administrative districts, the number of inhabitants per square kilometre ranges from 17 (Ciminà), in the innermost sectors, to 517 (Siderno) along the coast.

In the area, the main traffic lines are the Reggio Calabria - Metaponto railway line and the State road 106 which run parallel to the Ionian coast. The villages, which are located in the upper reaches of the basins, are accessible via secondary roads.

In order to reduce the devastating impact of natural disasters, the National Government has carried out consolidation works in many towns or forced the residents to move out. Following the 1951 DHE, most of the residents of Natile (located near Careri, Fig. 2), Canolo and Plati villages were evacuated.

\subsection{Climatic features}

The climate in southern Calabria is typically Mediterranean, characterised by hot and dry summers and long rainy periods in the autumn and in the winter, sometimes lasting until the early spring. Twelve climatic gauges, located between 7 and $970 \mathrm{~m}$ a.s.l., provide a good elevation coverage of the study area. Two of the gauges are also equipped for temperature measurement (Fig. 2B).
Available published data cover the period between 1916 to 1987 (daily rainfall data only from 1920, monthly and annual temperature only from 1937), but the rainfall and temperature time series contain many gaps, different for each gauge. Monthly rainfall data from 1988 to 1999 are also available. The minimum annual rainfall ranges between 281 and $1365 \mathrm{~mm}$, and the maximum values range between 1235 and $3754 \mathrm{~mm}$. The variability of annual rainfall affects the sequence of dry periods and disastrously wet years. The rainfall regime in the area is homogeneous. The wet season lasts from October to April, whereas minimum rainfall values are generally recorded in July. The Siderno rain gauge (No. 4), representing the local climatic regime, records a mean annual rainfall of $685 \mathrm{~mm}$ and a mean annual temperature of $17.8^{\circ} \mathrm{C}$ (Fig. 3). The thermal regime is moderate. The actual or net rainfall is greater than zero from October to April and totals $229 \mathrm{~mm}$ at Siderno. Mean annual rainfall and temperature are a function of altitude in the area.

The study area is homogeneous with respect to rainfall of short duration and high intensity (Versace et al., 1989).

Data on the river discharge have been gathered only for the Careri River (Fig. 2), over a monitoring period of 12 years.

\section{Data}

The period from 1916 to 1999 has been selected as a study period. Due to the partial availability of a historical series of daily rainfall, the analysis has covered the years from 1920 to 1987; the rainfall trend has been analysed throughout the study period.

Data on the phenomena which have occurred during the study period have been collected (Table 1). Information was inferred from technical and scientific publications (Caloiero and Mercuri, 1980; Catenacci, 1992; CNR-GNDCI, 1995; Petrucci et al., 1996), as well as from national and regional newspapers and from two databases (CNR-GNDCI, 1995; Petrucci and Versace, 2000). The analysis of the air photos, carried out only for specific sites, has helped to identify the types of phenomena and to interpret the historical data. A secondary subdivision into superficial and deep-seated landslides has been attempted. Only for 30\% of the analysed cases does the accuracy of description allow one to perform this classification. For this reason, this classification has been omitted, but, among unambiguous cases, deep-seated landslides are the vast majority.

Based on topographical maps (scale of 1:100000 and 1: $25000), 19$ hydrographic basins have been identified in the area, the largest of which reached the Ionian-Tyrrhenian watershed (Fig. 2A). The area has been subdivided into irregular cells by intersecting the perimeter of the hydrographic basins with the administrative borders of the 22 municipalities encompassed by the test site (Fig. 2B). The reported phenomena have been ascribed to the cells (Fig. 2C).

Two hundred and thirty-five phenomena have been reported over 26 time frames and classified as potential DHEs (Table 1). Each DHE was quite often triggered by various se- 

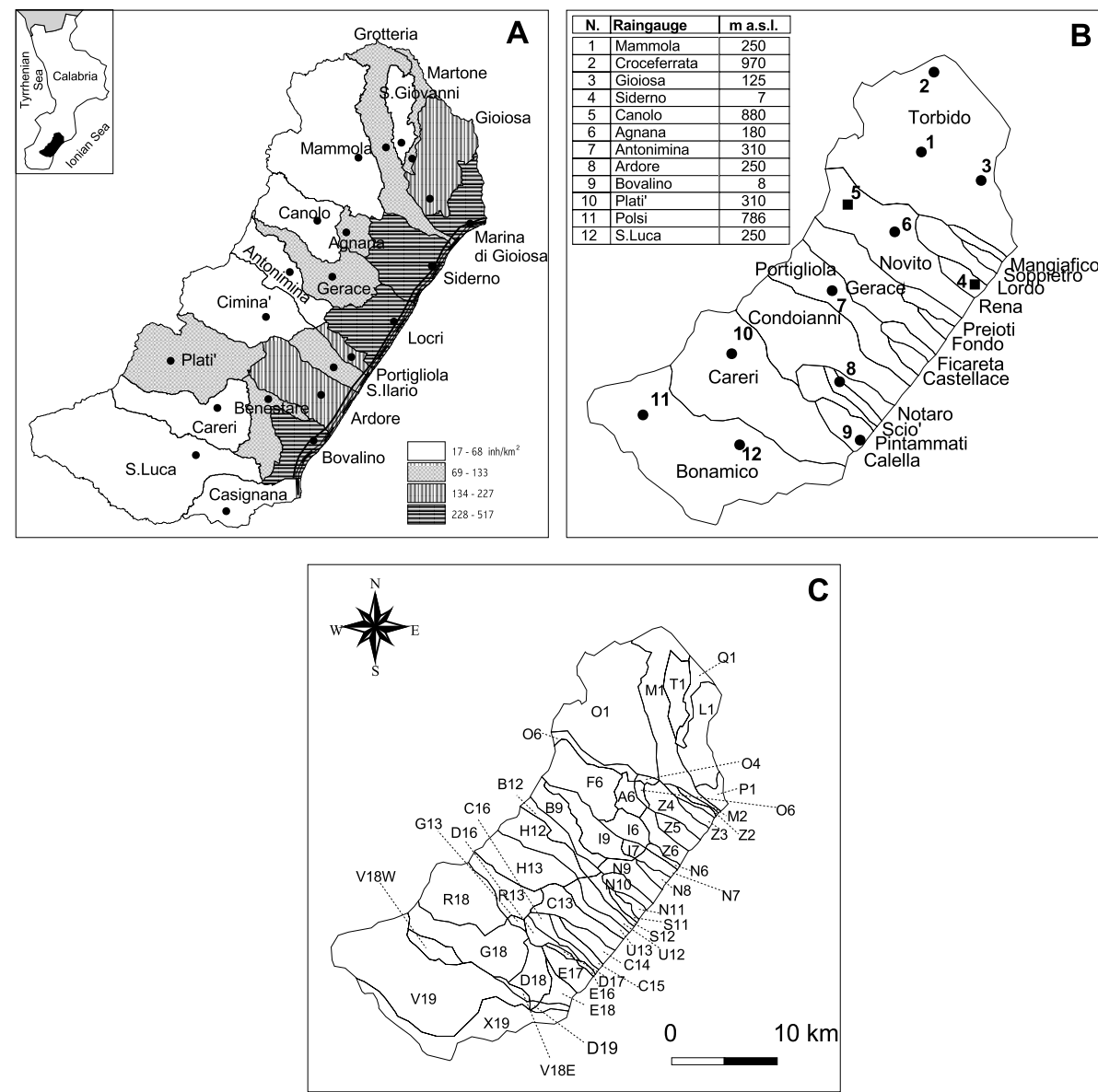

Fig. 2. Hydrographic and town boundary, cells and climatic gauges maps. (A) study area (top left) and municipal district classified based on population density (inhabitants $/ \mathrm{km}^{2}$ ), (B) drainage basins and rain (circle) and temperature (square) gauges; (C) cells obtained intersecting the (A) and (B) subdivisions of the study area.

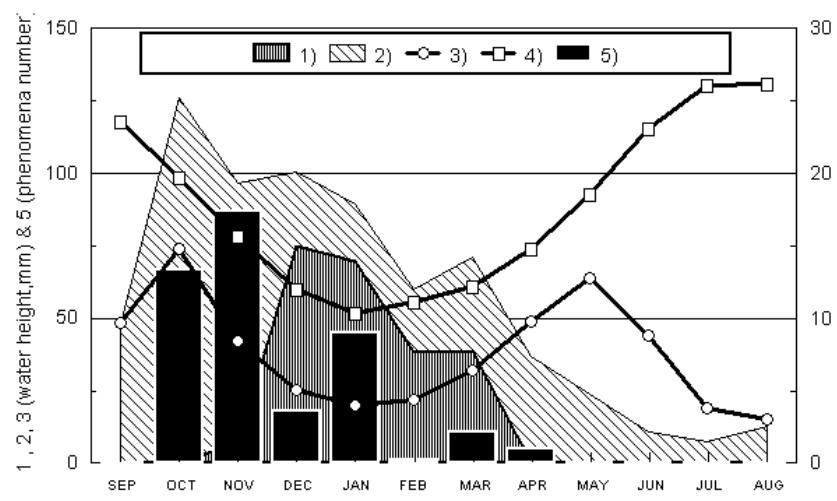

Fig. 3. Hydrological regimen and balance according to the Thorntwaite-Mather method (1957) for the mean hydrological year in a significant gauge (Siderno, gauge no. 4). Monthly values: (1) mean actual or net rainfall, (2) mean rainfall, (3) mean actual evapotranspiration, (4) mean temperature, (5) total number of phenomena occurred in the test area.

quences of rainy days. Three types of phenomena have been identified: landslides, floods and secondary floods.

The GEV functions have been set for each cumulative rainfall/duration/gauge. The return period of cumulative rainfall has been assessed and analysed for 26 events. Only 24 cases have shown a maximum return period greater than two years. The remaining two events - No. 16 and No. 19 - have been excluded as they were found to be abnormal.

\section{Results}

The first DHE for which data are available in the study area took place in 1927. The spatial database on the phenomena has been set up using all the available data for each kind of analysis, except for the return period evaluation of $C R_{n j}$, which was possible only for 18 DHEs which occurred before 1987.

Analysing the available data yielded by the 54 cells in the study area (about $686 \mathrm{~km}^{2}$ ), only 7 cells (about $19 \mathrm{~km}^{2}$, that is $3 \%$ of the study area) were found to be phenomena free.

\subsection{Regime, density and recurrence of the types of phe- nomena}

The phenomena span from October to April (Fig. 3). The relationship between the monthly number of phenomena and rainfall is low to null, particularly if actual rainfall is considered. This situation can be considered quite normal as phenomena are triggered by unusually heavy rainfall events and not by mean rainfall (utilised to draw Fig. 3). There 
Table 1. Data concerning the DHEs recorded in the Locride study area. The column DATE refers to the period during which the phenomena occurred. Abbreviations: L: Landslides, F: Floods, Sf: Secondary floods; E.P.: number of evacuated persons. N.A.: not available. The explanation of the notes in the table is: (1) each phenomenon can hit one or more cells; (2) the assessment is approximate as the maximum return period far exceeds the number of years for which data are available; (3) the evaluation is reasonably approximate due to the low rainfall data availability near the hit cells. Probably the high number of data depends on the fact that these events hit large portions of the Calabrian territory and the newspapers emphasized the damage also in areas not very strongly hit; (4) the event No. 24 can be classified as Type B only if the month of occurrence is not considered

\begin{tabular}{|c|c|c|c|c|c|c|c|c|c|c|c|}
\hline \multirow[t]{2}{*}{ No. } & \multicolumn{3}{|c|}{ Date } & \multirow{2}{*}{$\frac{\text { Hit cells }}{\text { Total Number }}$} & \multicolumn{2}{|c|}{ Phenomena (1) } & \multirow{2}{*}{$\begin{array}{l}\text { DHE } \\
\text { Type }\end{array}$} & \multirow{2}{*}{$\frac{\text { Return period }}{\operatorname{Max}(\mathrm{y})}$} & \multicolumn{3}{|c|}{ Damage } \\
\hline & Year & From & To & & Number & Type & & & Victims & E.P. & Level \\
\hline 1 & 1927 & $1 \mathrm{Dec}$. & 9 Dec. & 3 & 4 & L-F-Sf & $\mathrm{C}$ & 39 & 5 & 8 & High \\
\hline 2 & 1930 & 21 Feb. & - & 2 & 1 & $\mathrm{~F}$ & A & 4 & - & - & Low \\
\hline 3 & 1932 & 2 Mar. & - & 1 & 1 & $\mathrm{~L}$ & $\mathrm{~B}$ & 22 & - & - & Medium \\
\hline 4 & 1932 & 5 Nov. & 12 Nov. & 23 & 23 & L-F-Sf & $\mathrm{D}$ & 131 & 7 & 20 & High \\
\hline 5 & 1933 & 8 Dec. & - & 7 & 5 & L-F-Sf & $\mathrm{C}$ & 99 & - & - & High \\
\hline 6 & 1935 & 24 Nov. & - & 4 & 4 & L-F-Sf & $\mathrm{C}$ & 64 & - & - & Medium \\
\hline 7 & 1946 & 22 Jan. & - & 4 & 3 & Sf & $\mathrm{A}$ & N. A. & - & - & Low \\
\hline 8 & 1951 & 16 Oct. & $22 \mathrm{Oct}$ & 12 & 13 & L-F-Sf & $\mathrm{D}$ & > $1000(2)$ & 27 & 4300 & High \\
\hline 9 & 1953 & 18 Oct. & $7 \mathrm{Nov}$ & 33 & 45 & L-F-Sf & $\mathrm{D}$ & 58 & - & 406 & High \\
\hline 10 & 1955 & 25 Jan. & - & 15 & 7 & L-F-Sf & $\mathrm{C}$ & 10 & - & 10 & Medium \\
\hline 11 & 1958 & 26 Nov. & $29 \mathrm{Nov}$ & 20 & 16 & L-F-Sf & $\mathrm{C}$ & 13 & - & 10 & Medium \\
\hline 12 & 1959 & 14 Nov. & $26 \mathrm{Nov}$ & 21 & 10 & L-F-Sf & $\mathrm{C}$ & $>3(3)$ & - & - & Medium \\
\hline 13 & 1966 & 9 Oct. & - & 7 & 4 & L-F-Sf & $\mathrm{C}$ & 14 & - & - & Medium \\
\hline 14 & 1971 & 1 Oct. & 3 Oct & 19 & 18 & L-F-Sf & $\mathrm{C}$ & 14 & - & - & Medium \\
\hline 15 & 1972-1973 & 22 Dec. & 6 Jan & 19 & 23 & L-F-Sf & $\mathrm{D}$ & $>200(2)$ & - & 387 & High \\
\hline 16 & 1974 & 15 Feb. & - & 1 & 1 & $\mathrm{~L}$ & B & $<2$ & - & - & Low \\
\hline 17 & 1975 & 7 Nov. & - & 4 & 5 & L-F-Sf & $\mathrm{C}$ & $>3(3)$ & - & 200 & Medium \\
\hline 18 & 1976 & 25 Oct. & $6 \mathrm{Nov}$ & 12 & 16 & L-F-Sf & $\mathrm{C}$ & 24 & - & - & Medium \\
\hline 19 & 1978 & 20 Jan. & - & 3 & 4 & L-Sf & $\mathrm{B}$ & $<2$ & - & - & Low \\
\hline 20 & 1985 & 18 Jan. & - & 1 & 2 & $\mathrm{~L}$ & $\mathrm{~B}$ & 3 & - & - & Low \\
\hline 21 & 1987 & 15 Nov. & - & 4 & 1 & $\mathrm{~F}$ & A & 3 & - & - & Low \\
\hline 22 & 1988 & 6 Mar. & - & 11 & 3 & $\mathrm{~L}$ & B & N. A. & - & - & Low \\
\hline 23 & 1991 & 19 Mar. & - & 1 & 2 & $\mathrm{~L}$ & B & N. A. & - & - & Low \\
\hline 24 & 1994 & 6 Nov. & - & 2 & 2 & $\mathrm{~L}$ & $\mathrm{~B}$ & N. A. (4) & - & - & Low \\
\hline 25 & 1995 & 14 Mar. & 17 Mar. & 7 & 5 & L-Sf & B & N. A. & - & - & Low \\
\hline 26 & 1996 & 15 Jan. & 31 Jan. & 15 & 17 & L-F-Sf & $\mathrm{C}$ & N.A. & - & - & Medium \\
\hline
\end{tabular}

are two reasons for this. If we consider the type of phenomena occurring during October and November, the two months characterised by the maximum monthly number of phenomena, more than $40 \%$ are landslides. At the end of the arid season in a Mediterranean area, between September and October, when the actual evapotranspiration is more or less equal to the monthly maximum value, clay slopes are particularly liable to quick infiltration of large amounts of rainfall. On the other hand, during October, the high pressure, which dominates the Mediterranean summer, generally collapses quite abruptly, triggering heavy rainfall (Petrucci and Polemio, 2002). Both conditions contribute to landsliding and flooding. Four thematic maps, plotting the values of $D_{c}$ for landslides (Fig. 4A), floods (Fig. 4B), secondary floods (Fig. 4C) and total phenomena (Fig. 4D), have been drawn applying (Eq. 1).

When analysing landslide distribution, about $40 \%$ of the study area showed a medium density. That was particularly true for the mountain sectors which exhibited markedly steep slopes with flysch outcroppings, particularly prone to landsliding. In these sectors, the vast majority of data refer to landslides which have affected the internal road network. The maximum value of the landslide density is recorded in the coastal cell (N8). However, when analysing this density, it is worth remembering that $\mathrm{N} 8$ is one of the most populated cells: the presence of a great number of elements at risk ensures that all the occurred phenomena, having damaged some element, have been recorded. This is not true for poorly populated cells, where old phenomena that have caused no damage have gone unrecorded. Flood density is higher in the coastal sectors, which are characterised mostly by lowlands, and lower in the high basins. As is the case for landslides, the maximum density characterises the most populated district, where the presence of elements at risk along the river network interferes with the natural development of river floods and allows the recording of an event. The high concentration of damaging flood data at the valley outlet also depends on the abrupt decrease of the bed slope, typical of fiumare. 

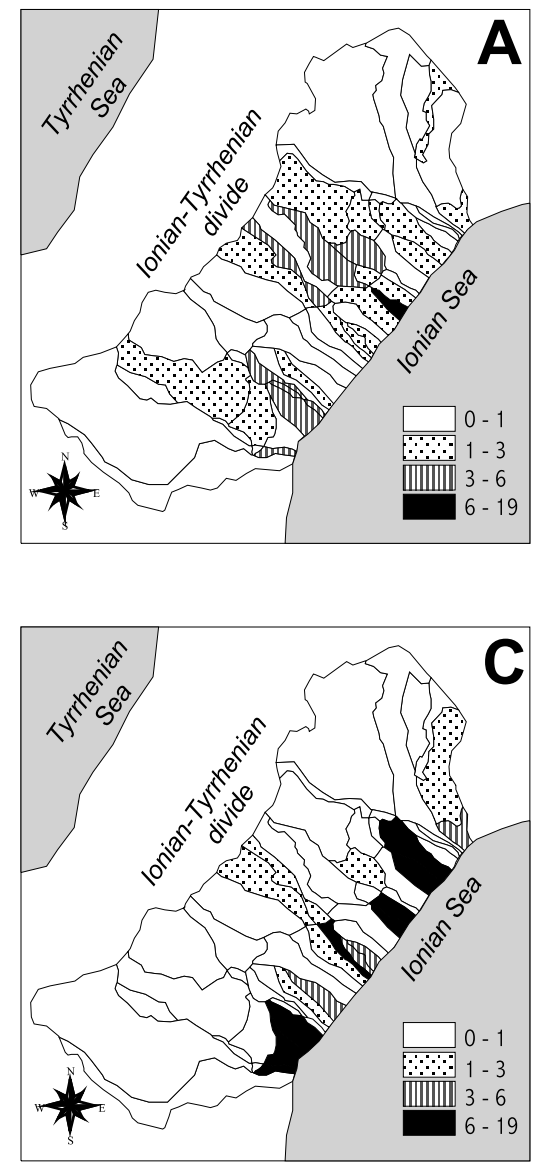
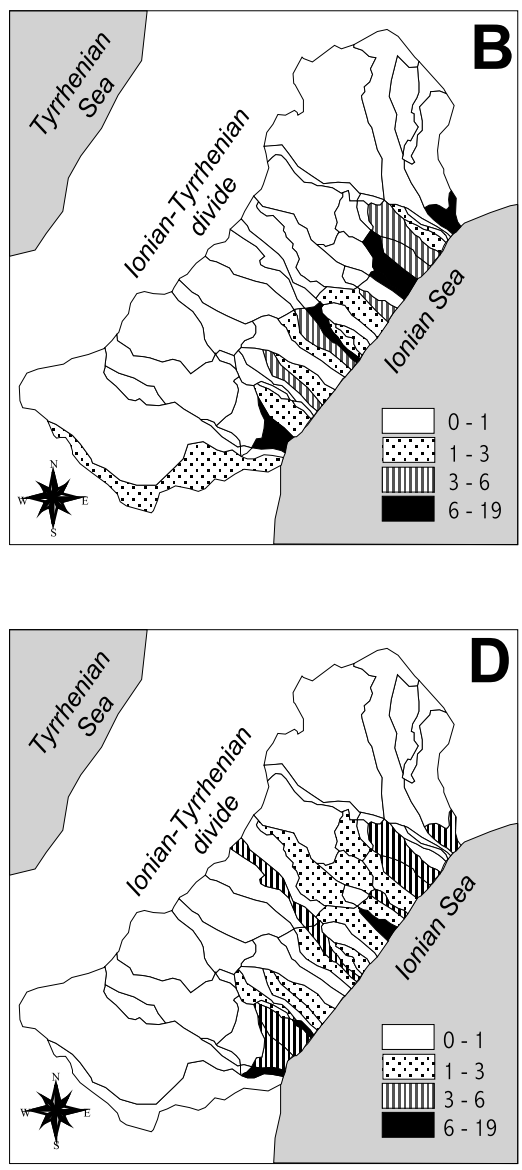

Fig. 4. Phenomena density $D_{c}$ $\left(10^{-4} / \mathrm{km}^{2}\right)$ maps. (A) landslide; (B) flood; (C) secondary flood; (D) all phenomenon types. The phenomena number is multiplied by a factor of $10^{4}$ to obtain a density greater than 1 .
Four thematic maps, plotting the values of $T_{C}$ for landslides (Fig. 5A), floods (Fig. 5B), secondary floods (Fig. 5C) and total phenomena (Fig. 5D), have been drawn applying (Eq. 2), with $\Delta T$ equal to 72 years (period between 1927 and 1999).

The low landslide recurrence time in the mountain cells confirmed these sectors as particularly prone to landslides. The lower time recurrence classes (between 6 and 18 years) cover about $60 \%$ of the study area. Values of landslide recurrence below 6 years characterise two cells alone: I9 and G18. For both cells, the historical series of landslide is very long. I9 cell, correspond to the old Calabrian town of Gerace, the historical series of phenomena is as old as the town itself (Petrucci and Polemio, 2000). As for the G18 cell, the high recurrence is linked to the re-activation of a huge landslide involving the road to the village of Careri.

In the central portion of the study area, flooding can be equally threatening, particularly for two major basins in the area (Torbido and Bonamico Rivers). In both cases, the presence of small villages in the innermost sectors amplifies the effect of the damaging events.

Secondary floods are very common inland and along the coast, but they show lower recurrence time than floods. Higher values characterise the towns of Siderno and Bovalino, most likely due to the inefficient urban drainage sys- tems. In the urban areas along the coast, these phenomena result from floods of small streams which intersect the urban area, especially where the river section has been artificially reduced close to roads or railway bridges.

Most of the study area (83\%) has been hit by at least one of the above described phenomena over a period ranging from 3 to 15 years.

One of the most catastrophic DHEs is described in Fig. 6. This event claimed 64 lives all over Calabria and 27 in Locride. Fatalities were concentrated mainly in two areas: 15 deaths were caused by the disastrous flood of Careri River, in the Plati village, 10 by a wide landslide that occurred near Canolo and 2 by a landslide in the Bovalino village (Event No. 8 in Table 1; see also Fig. 6). Landslides and floods, from inland to the coast mainly hit the central-southern sector of the study area. The critical rainfall duration was less than 30 days, but cumulative rainfall of 5 days reached the highest return period (163 years) and a total of $793 \mathrm{~mm}$ of cumulative rainfall.

\subsection{Trend of phenomena and climatic change}

The annual rain index $\operatorname{Ir}_{y}$ (3) has been calculated for the whole area (Fig. 7). Phenomena were often concentrated in those years when the rainfall rate was particularly high. If years with more than 10 phenomena are considered, the min- 

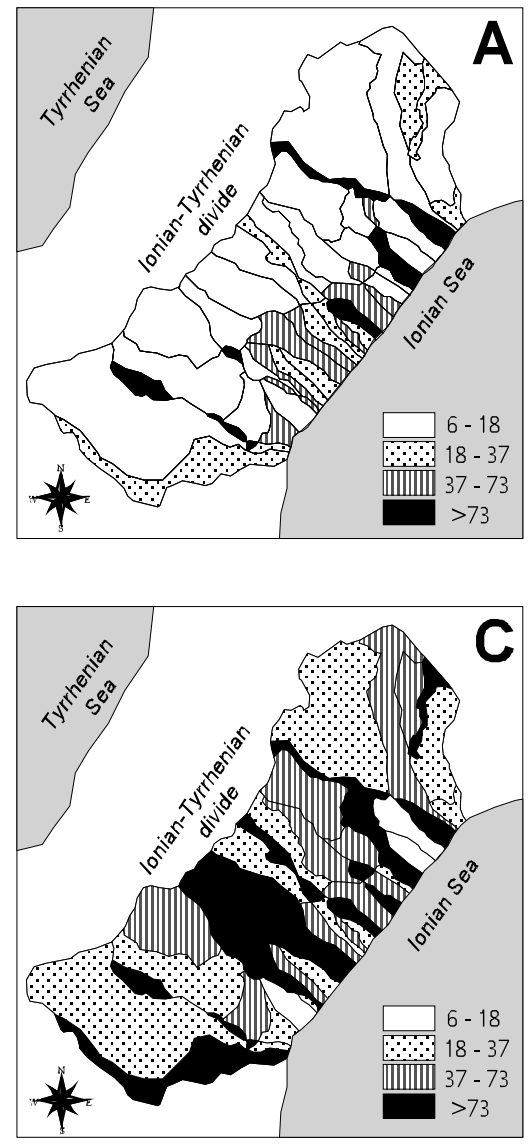
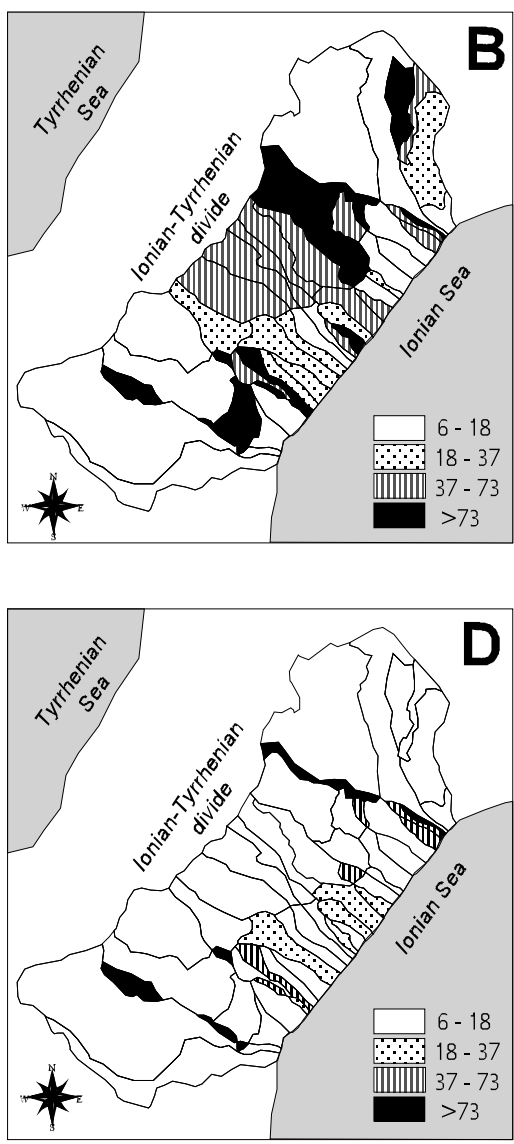

Fig. 5. Phenomena recurrence time $T_{c}$ (years) maps. (A) landslide; (B) flood; (C) secondary flood; (D) all phenomenon types. Recurrence class ranges are optimised to obtain the best representation of spatial variability. imum $\operatorname{Ir}$ is equal to $102 \%$, the mean to $147 \%$ and the maximum to $226 \%$.

The rainfall rate trend was then calculated in the area, using the regression line (Fig. 7). Over the past 80 years, a drop in the rainfall rate has occurred, that is about $20 \%$ of the current mean value. The trend of phenomena was characterised by determining $P N_{10, y}$ as the total number of phenomena of the previous 10 years, starting from year $y$. Higher $P N_{10, y}$ are related to the period 1954-1963; from 1987 extremely low $P N_{10, y}$ values were observed. The gradient of the $P N_{10, y}$ regression line is slightly negative, equivalent to a decreased 1.2 phenomena in 80 years. This decrease is certainly under assessed due to the probable lack of data collection regarding phenomena that occurred during the first part of the last century.

The statistical linear correlation between $A P_{i}$ and the number of phenomena is low, but not null (the correlation coefficient is equal to 0.62 ). As a consequence, the observed lowering rainfall trend could contribute to justify the recent drop in the number of phenomena.

A very low increase in the annual temperature has also been observed based upon the available data. In any case, rainfall drop and temperature increase reduce the actual or net rainfall, thus contributing to a reduction in the probability of a DHE occurrence.

\subsection{DHE classification}

The analysis has identified four major types of DHEs which have occurred in the study area. They have been sorted based on the increasing severity of the resulting damage. This sorting has highlighted clear differences in the spatial distribution, as well as the season and the return period of triggering rainfall. All the characteristics of the DHEs have been summarised in Fig. 8.

- Type A covers the coastal sectors and causes river outflows and/or widespread secondary flooding between November and January. The most critical rainfall duration ranges between 1 and 20 days, whereas the return period is less than 10 years. The severity of induced damage, according to the levels proposed in Sect. 3.4, is low.

- Type B hits the most internal cells generally between January and March (except for event No. 24). It is associated with heavy rainfall and return periods below 30 years. Higher return periods are due to cumulative rainfall 1 - to 10 -days in duration. The most commonly triggered phenomena are landslides, sometimes together with secondary floods. The severity of damage is low to medium. 

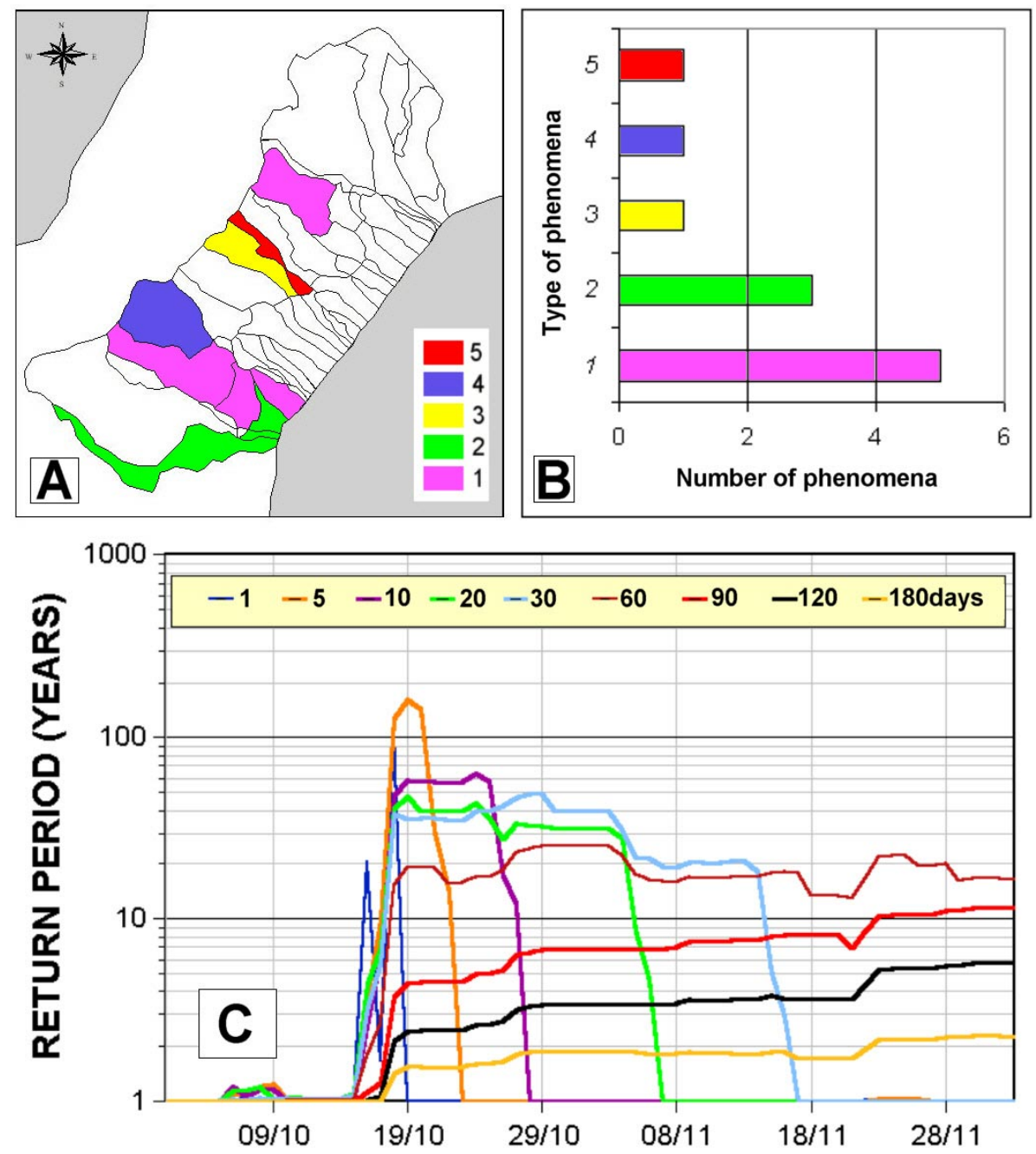

Fig. 6. (A)-(B) Types of phenomena induced by 1951 event and their distribution on the study area. $1=$ landslides; 2 = floods; 3 = secondary floods; 4 = landslides and floods; 5 = landslides and secondary floods. (C) Return period (years) of daily cumulative rainfall 1 to 180 days in Antonimina gauge (No. 7).

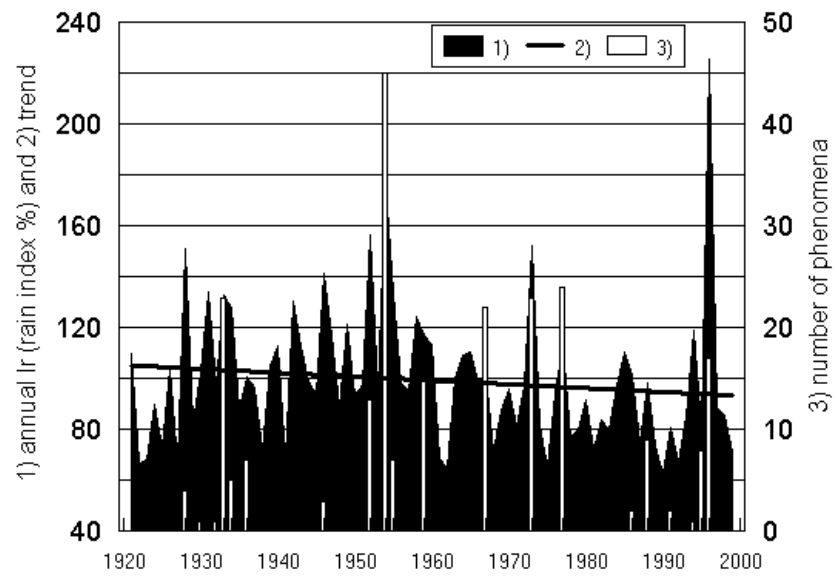

Fig. 7. Rainy annual index $I r$ and annual number of phenomena versus hydrologic years (from September to August). (1) Ir (\%), (2) $\operatorname{Ir}$ regression line, (3) annual number of phenomena.

- Type C, occurring between October and January, causes all types of phenomena. It hits from inland to the coast in the central and southern part of the area. These events occur after rainy periods which generally last less than 60 days. The most exceptional cumulative rainfall lasts less than 30 days and has a return period of less than 50 years. The severity of damage is medium to high.

- Type D is the most devastating, as was the case for the 1951 event (Fig. 6). These events occur between October and December and are characterised by widespread effects across the whole study site. The triggering rainfall has a critical duration of less than 60 days and is unusually heavy, with return periods exceeding 50 years. Generally speaking, the most unusually heavy rainfall lasts 5 to 60 days. The severity of damage is high, the number of fatalities is remarkable and there are repercussions on the local economy.

\section{Conclusions}

Damaging Hydrogeological Events are a source of "multiple hazardous events", as they can simultaneously trigger different types of phenomena, such as landslides, floods and 


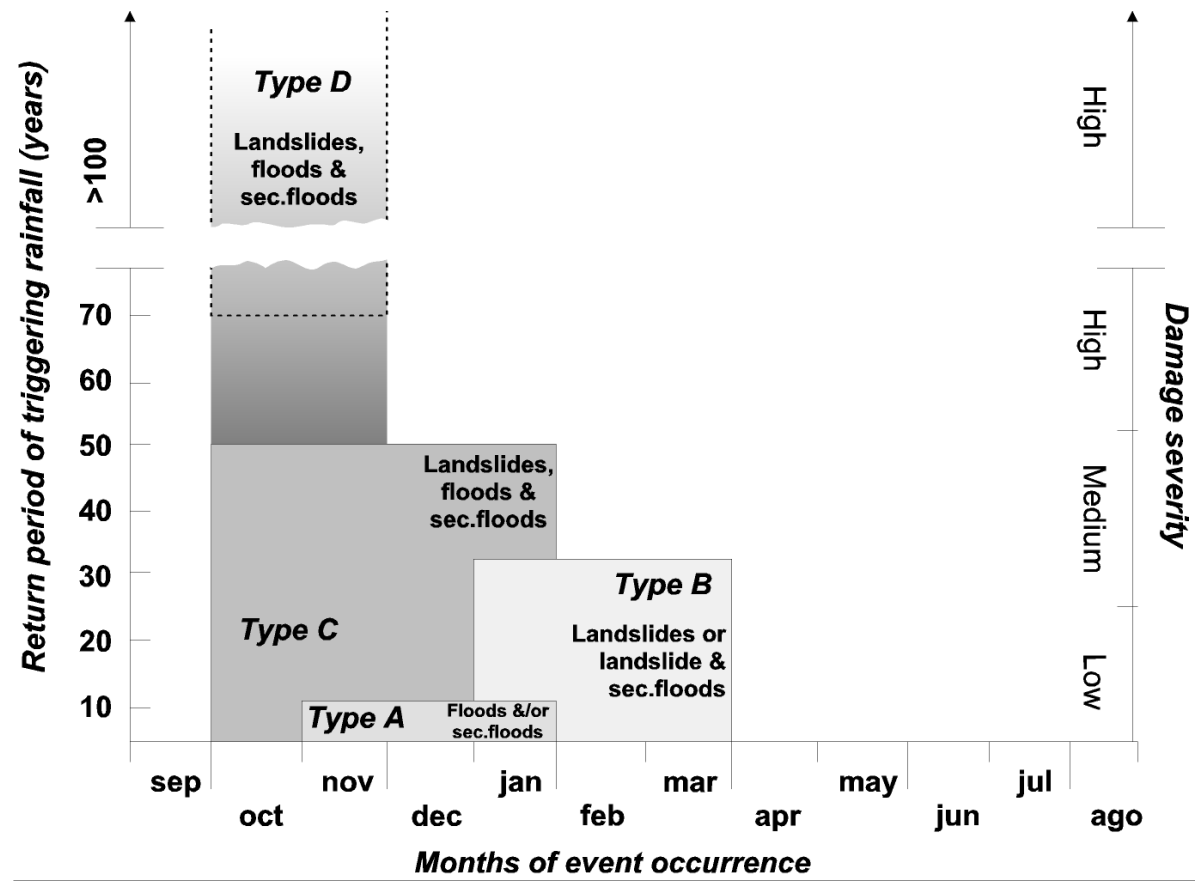

Fig. 8. Different types of DHE occurring in the study area characterised using return period of triggering rainfall, month of occurrence, damage severity and type of triggered phenomena. secondary floods. Hence, a comprehensive approach, which covers all kinds of phenomena, has been designed in order to elucidate the relationships with the concurrent triggering rainfall.

In this paper a methodology aimed at characterising DHEs has been proposed. The proposed event characterisation method is intended to evaluate DHE-related hazardous events in terms of recurrence, damage severity and extension of the affected area. Based on the analysis of the distribution of phenomena during DHEs, which has drawn heavily on historical data, and the comparison with the triggering rainfall, the different recorded DHE scenarios can been identified and sorted.

The methodology has been tested in a study area, about $686 \mathrm{~km}^{2}$ in size, located in Southern Italy. Two hundred and thirty phenomena were recorded during 24 DHEs, in a period of 80 years (from 1920 to 1999). Four main types of DHE, causing damage of increasing severity from Type A to $\mathrm{D}$, have been found. The type $\mathrm{D}$, the most threatening one, produces extremely severe damage, claims many lives and results in serious economic losses. The rainfall rate trend was characterised. Over the past 80 years, a drop in the rainfall rate has occurred, that is about $20 \%$ of the current mean value. The observed decrease in the rainfall trend seems to justify the recent drop in the number of phenomena.

The proposed methodology can be applied to different climatic and geomorphological settings. A methodology limitation is due to the type of historical data that does not permit the exact phenomenon georeferencing, except for particular types of cells, as proposed by the authors. The cells were in fact obtained by crossing watershed and administrative boundaries. As a consequence, only a preliminary evalua- tion of damaging phenomena density can be obtained.

One of the future methodological developments may be based on the identification of the possible "crisis points" and on the analysis of the type of DHE which is most likely to bring on a crisis. These insights can help classify the territory into areas prone to certain types of DHEs with a specific range of recurrence time and with specific forecast damage. If the actual configuration of the elements at risk is taken into account, the expected damage can be roughly evaluated in each scenario. The likely post-event setting can yield useful data for the implementation of accurate emergency public health safety programmes by knowing the scenarios of the past events it will be possible to appropriately select the population gathering points and the communication lines which are not at risk. These paths can be used to evacuate the population and permit the passage of means of transport and rescue teams into and from the affected area.

In addition, insights can be gained into pre-event weather conditions and assist in DHE-forecasting.

\section{Perspectives}

This approach could prove to be a valuable tool to guide the planning of hydrogeological monitoring activities, to optimise the planning and design of future engineering works, mainly roads, railways, as well as the planning of new urban areas, which are often threatened by DHEs.

The planning of a monitoring network can be based on a gauge density as a function of the hazard for each cell. The monitored variables, the instrumentation and means of data transmission and acquisition can be selected and optimised 
in accordance with the expected critical duration of rainfall for the expected type of DHE in each cell.

The planning and design of future engineering works may benefit from the body of knowledge on DHEs. Insights into the recurrence times of the most devastating floods may lead to modifications in the project provisions for bridges - in terms of return period of forecast flood - and waterways in a given area.

The experimentation of the proposed methodology will follow two lines of development. On the one hand, the data set will be expanded so as to include data referring to daily and monthly temperature up to the previous year. The most recent DHEs can thus be fully characterised. Moreover, new procedures for the analysis of data will be substantiated and the role of climatic changes, in particular changes in temperature, will be better elucidated. At the same time new geomorphological approaches will be studied to reduce the approximation due to the use of the proposed type of cells.

On the other hand, the search for new test sites will begin taking into consideration areas with different hydrological, climatic and human features, in collaboration with other research teams.

Acknowledgements. The authors owe thanks to the national hydrologic service (Servizio Idrografico e Mareografico Nazionale) which supplied rainfall and temperature data and to two anonymous referees whose suggestions have remarkably improved this article.

\section{References}

AA.VV.: Advisory Board on the Built Environment, Commission on Engineering Technical Systems and National Research Council: Report on a Workshop on Mitigation Strategies for Communities Prone to Multiple Natural Hazards. Snowmass, Colorado 6-8 July 1983. National Academic Press, Washington D.C, 1-22, 1983.

Amodio-Morelli, L., Bonardi, G., Colonna, V., Dietrich, D., Giunta, G., Ippolito, F., Liguori, V., Piccarreta, G., Russo, M., Scandone, P., Zanettin-Lorenzoni, E., and Zuppetta, A.: L'arco CalabroPeloritano nell'orogene appenninico-maghrebide, Mem. Soc. Geol. It., 17, 1-60, 1976.

Antronico, L., Petrucci, O., Scalzo, A., and Sorriso-Valvo, M.: Relationships between land degradation forms and historical development of malaria in Calabria, Int. Jour. Anthropology, 13, 3/4, 211-217, 1998.

ASCE: Hydrology handbook. American Society of Civil Engineers, Manuals and Report No. 28, 784 pp, 1996.

$\mathrm{Au}, \mathrm{S}$. W. C.: Rain induced slope instability in Hong Kong. Eng. Geol., 51, 1-36, 1998.

Baker, V. R., Kochel, R. C., and Patton, P. C. (Eds): Flood Geomorphology, John Wiley and Sons Inc., New York, 503 pp., 1988.

Boschi, E., Guidoboni, E., Ferrari, G., Valensise, G., and Gasperini, P.: Catalogo dei forti terremoti in Italia dal 461 a.C. al 1990, Istituto Nazionale di Geofisica e SGA Storia Geofisica Ambiente (Eds), Bologna, 644 pp., 1997.

Caine, N.: The rainfall intensity-duration control of shallow landslides and debris flows, Geografiska Annaler. 62A, 1/2, 23-27, 1980.
Caloiero, D. and Mercuri, T.: Le alluvioni in Calabria dal 1921 al 1970, CNR-IRPI Rende (CS), Geodata No. 7, 161 pp., 1980.

Campbell, R.: Soil slips, debris flows and rainstorms in the Santa Monica Mountains and vicinity, Southern California, USGS Professional Paper, 851, 51 pp., 1975.

Canuti, P. and Casagli, N.: Considerazioni sulla valutazione del rischio da frana, CNR-GNDCI, Linea 2, U.O. 2.14, Pubb. No. 846, Firenze, 57 pp., 1996.

Cascini, L. and Versace, P.: Eventi pluviometrici e movimenti franosi, Atti Convegno Nazionale di Geotecnica, Bologna, 3, 171184, 1986.

Capecchi, F. and Focardi, P.: Rainfall and landslides: research into a critical precipitation coefficient in an area of Italy, Proc. 5th Symp. on Landslides. Lausanne, 1131-1136, 1988.

Catenacci, V.: Il dissesto idrogeologico e geoambientale in Italia dal dopoguerra al 1990, Cronistorie Calabresi. S.G.N., Mem. Carta Geologica d'Italia. Ist. Poligrafico e Zecca dello Stato, XLVII, 228-245, 1992.

CNR-GNDCI: Progetto AVI, Censimento delle aree vulnerate da calamità idrogeologiche, Rapporto di sintesi, Calabria. Grifo, Perugia, 40 pp., 1995.

Corominas, J.: Landslides and climate. Keynote Lectures from the 8th International Symposium on Landslides, 4, 1-33. ISBN No. 0-954 1992-0-0, 2001.

Crozier, M. J.: Landslides: causes, consequences and environment. Croom Helm, 252 pp., 1986.

De Vita, P. and Reichenbach, P.: Rainfall triggered landslides: a reference list, Environmental Geology, 35, 2/3, 219-233, 1998.

Flageollet, J. C., Maquaire, O., Martin, B., and Weber, D.: Landslides and climatic conditions in the Barcelonette and Vars basins (Southern French Alps, France), Geomorphology, 30, 65-78, 1999.

Gare, P. A., Douglas, J. S., and Nordstrom, K. F.: Geomorphology and natural hazards, Geomorphology, 10, 1-18, 1994.

Govi, M. and Turitto, O.: Problemi di riconoscimento delle fasce di pertinenza fluviale, Atti IV Conv. Int. Geoingegneria "Difesa e valorizzazione del suolo e degli acquiferi”, Torino, 1, 161-172, 1994a.

Govi M., and Turitto, O.: Ricerche bibliografiche per un catalogo sulle inondazioni, piene torrentizie e frane in Valtellina e Valchiavenna, Ass. Min. Subalpina, Quad. di Studi e Documentazione, 16, 247 pp., 1994b.

Govi, M., Mortara, G., and Sorzana, P. F.: Eventi idrologici e frane, Geol. Appl. and Idrogeol., XX, 2, 359-375, 1985.

Guerricchio, A. and Melidoro, G.: Segni premonitori e collassi delle grandi frane nelle metamorfiti della valle della fiumara Bonamico (Aspromonte, Calabria), Geol. Appl. and Idrogeol., 8, II, 315346, 1973.

Guidoboni, E.: Dati di base e metodo di indagine: una navigazione fra effetti sismici e contesti storici, Istituto Nazionale di Geofisica e SGA Storia Geofisica Ambiente editori, Bologna, 20$57,1995$.

Guzzetti, F.: Landslide fatalities and the evaluation of landslide risk in Italy, Engineering Geology, 58, 89-107, 2000.

Hosking, J. R. M., Wallis, J. R., and Wood, E. F.: Estimation of the generalised extreme value by the method of probability-weighted moments, Technometrics, 27 (3), 251-261, 1985.

Ibbeken, H. and Schleyer, R.: Source and sediment, a case study of provenance and mass balance at an active plate margin (Calabria), Springer Verlag, 286 pp., 1991.

Ibsen, M. L. and Brunsden, D.: The nature, use and problems of historical archives for the temporal occurrence of landslides, with 
specific reference to the South coast of Britain, Ventnor, Isle of Wight, Geomorphology, 15, 241-258, 1996.

Iovine, G. and Petrucci, O.: Effetti sui versanti e nel fondovalle indotti da un evento pluviale eccezionale nel bacino di una fiumara calabra (T. Pagliara), Boll. Soc. Geol. It., 117, 821-840, 1998.

Jenkinson, A. F.: The frequency distribution of the annual maximum (or minimum) values of meteorological elements, Q. J. Roy. Meteo. Soc., 81, 158-171, 1955.

Keefer, D. K., Wilson, R. C., Mark, R., Brabb, E. E., Brown, W. M. III, Ellen, S. D., Harp, E. L., Wieczorek, G. F., Alger, C. S., and Zatkin, R. S.: Real time landslide warning during heavy rainfall, Science, 238, 921-925, 1987.

Krzysztofowicz, R.: The case for probabilistic forecasting in hydrology, J. of Hydrology, 249, 2-9, 2001.

Lanzafame, G. and Mercuri, T.: Interruzioni ferroviarie in Calabria conseguenti a fenomeni naturali (1950-1973), CNR-IRPI, Rende (CS), Geodata No. 3, 46 pp., 1975.

Maraga, F.: Delimitazione di aree inondabili secondo criteri geomorfologici, Boll. Soc. Geol. It., 45, 247-252, 1990.

Marco, J. B. and Cayuela, A.: Urban flooding. The flood planned town, Pre-proc. of the NATO ASI "Coping with floods", Erice, 3-15 November, 337-353, 1992.

Naden, P. S., Calver, A., Reed, D. W., and Reynard, N. S.: Rainfallinduced landslides: a hydrological perspective, Report to CEC, EPOCH contract 0029, Bruxelles, 1993.

Natale, L. and Versace, P.: Programmi di previsione e prevenzione del rischio idraulico e geologico, Atti del Corso di Aggiornamento: La sistemazione dei corsi d'acqua naturali, a cura di U. Maione and A. Brath. Politecnico di Milano, 443-459, 1995.

Petrucci, O., Chiodo, G., and Caloiero, D.: Eventi alluvionali in Calabria nel decennio 1971-1980. GNDCI, Pubb. 374. Rubbettino Arti Grafiche, Soveria Mannelli (CZ), 142 pp., 1996.

Petrucci, O. and Polemio, M.: Il dissesto della rupe di Gerace: patrimonio artistico e fattori idrogeologici di rischio, Atti Convegno GEOBEN 2000, Condizionamenti geologici e geotecnici nella conservazione del patrimonio Storico Culturale, Torino, 7-9 June 2000, 775-782, 2000.

Petrucci, O. and Polemio, M.: Hydrogeological multiple hazard: a characterisation based on the use of historical data, Ist European Conference on Landslides, 24-26 June 2002, Prague, 269-274, 2002.

Petrucci, O. and Versace, P.: Conoscere il passato per prevedere il
futuro,Dipartimento Protezione Civile Informa, 29, 25-26, 2000.

Polemio, M.: Le calamità idrogeologiche dell'inverno 1995-1996 nel territorio tarantino. Conv. Int. "La prevenzione delle catastrofi idrogeologiche: il contributo della ricerca scientifica”, CNR IRPI, Alba, November 1996, 2, 63-73, 1998.

Polemio, M. and Petrucci, O.: Rainfall as a landslide triggering factor: an overview of recent international research. The 8th International Symposium on Landslides in Cardiff in the year 2000, June 2000, E. Bromhead, N. Dixon and M.L. Ibsen editors, 3, 1219-1226, 2000.

Polemio, M. and Sdao, F.: The role of rainfall in the landslide hazard: the case of the Avigliano urban area (Southern Apennines, Italy), Engineering Geology, 53, 3-4, 297-309, 1999.

Rosgen, D. L.: A classification of natural rivers, Catena, 22, 169199, 1994.

Samuels, P. G.: An overview of flood estimation and flood prevention, Kassel Reports of Hydraulic Engineering, 9, G1-G11, 2000.

Sandersen, F., Bakkehøi, S., Hestnes, E., and Lied, K.: The influence of meteorological factors on the initiation of debris flows, rockfalls, rockslides and rockmass stability, Landslides, Proc. of 7th Int. Symp. on Landslides. Trondheim, Senneset (Ed) Rotterdam, Balkema. 1, 97-113, 1996.

Schultz, G. A.: Rainfall-runoff models for flood management using remote sensing data, Kassel Reports of Hydraulic Engineering, 9, D1-D41, 2000.

Ubertini, L.: Real-time flood forecast activity by CNR-National Research Group for Prevention of Hydrogeological Hazard, Mem. Soc. Geol. It., 45, 163-171, 1990.

Thornthwaite, C. W. and Mather, J. R.: Instructions and tables for computing potential evapotranspiration and the water balance, Drexel Inst. of Climat., Centerton, 10, 323 pp., 1957.

Versace, P., Ferrari, E., Gabriele, S., and Rossi, F.: Valutazione delle piene in Calabria, CNR-IRPI, Rende (CS), Geodata No. 30, 220 pp., 1989.

Wieczoreck, G. F.: Effect of rainfall intensity and duration on debris flows in central Santa Cruz Mountains, California, Geol. Soc. of America, Review in Eng. Geol., VII, 93-104, 1987.

Yevjevich, V.: Technology for coping with floods in the 21st Century, Pre-proc. of the NATO ASI "Coping with floods", Erice, 3-15 November, 1992, 43-51, 1992. 